UDC 531.768: 621.316.73(045)

DOI:10.18372/1990-5548.64.14854

\author{
${ }^{1}$ M. P. Mukhina, \\ ${ }^{2}$ S. I. Ilnytska, \\ ${ }^{3}$ O. A. Lazarevskyi
}

\title{
COMPARISON OF TIME DOMAIN STEP COUNTING METHOD FOR PEDESTRIAN DEAD RECKONING
}

\author{
${ }^{1,3}$ Faculty of Air Navigation, Electronics and Telecommunications National Aviation University, \\ Kyiv, Ukraine \\ ${ }^{2}$ Institute of Laser and Optoelectronics Intelligent Manufacturing, Wenzhou University, \\ Wenzhou, China \\ E-mails: ${ }^{1}$ mukhina@nau.edu.ua, ${ }^{2}$ ilnytskasv84@gmail.com, ORCID 0000-0003-2568-8262, \\ 3darkkemono@gmail.com
}

\begin{abstract}
The problem of step counting has been considered for personal navigation while walking and using mobile sensors with low accuracy. Step counting has been realized by three main methods of processing the acceleration vector magnitude in time domain. The comparison of this methods has been done while processing the data from mobile phone sensors for different conditions and types of pedestrian/their motion patterns. In order to have representative statistics the walking trajectories have been selected long enough (at least 100 meters) except the method of normalized auto-correlation based step counting where short distances have been processed. The requirements to definite method of step counting have been formulated.
\end{abstract}

Index Terms-Pedestrian dead reckoning; autocorrelation function; thresholding; peaks detection; zero crossing.

\section{INTRODUCTION}

The problem of pedestrian dead reckoning (PDR) is referred to the class of individual navigation problems [1]. The common solution in mobile phones is the use of satellite navigation (GPS, GLONASS, Galileo, etc). But satellite signal sometimes can be jammed intentionally or lost due to obstacles in urban area. Also the problem of PDR is interesting in the user localization in indoor environment such as large garages, city molls, etc.

Instrumentation of smartphones is now based on Micro-Electro-Mechanical Sensors (MEMS) technology and includes standard set of Inertial Measurement Unit (IMU): accelerometers, gyroscopes, magnetometers and pressure sensor (optionally).

Accelerometers can be used to detect step events and further to calculate lengths. But it is sensitive to walking speed, slope of the road, etc., which leads to inaccurate results of calculating the stride length. Also as any dead reckoning technique PDR suffers from the cumulative error. Since the location estimate is always calculated based on the previous result, the error accumulates rapidly over time. This means that correction updates are necessary on regular basis.

For example, the error in determining the direction has a greater effect on the estimation of the location than the error in calculating the step length.
The readings of magnetometers and gyroscopes can be used to calculate the course. However, the magnetometer is exposed to electric current and metals in the environment; the gyroscope has a drift problem, which means that the reading error increases with time. Besides, tilting the smartphone can lead to a deviation of its course from the direction of user walking. Smartphone poses also contributes to course accuracy, which must be considered in practice.

The crucial question is how to detect the step by IMU readings. There are a variety of different methods and techniques [2]: zero crossing, peak detection, normalized auto-correlation based step counting, etc.

The threshold method [3] is based on counting the steps by detection of reaching the threshold of sensor readings (usually accelerometers). But the value of threshold depends on sensor type and also on the walking pattern of pedestrian. However, though the threshold method is the simplest, it is mostly related to empirical techniques, since the optimal threshold for all the cases does not exist, especially when smartphones are used in an unconstrained manner.

The peak detection method [4] calculates steps based on the number of peaks in accelerometer vector magnitude. It is more flexible but suffers from interference peaks due to environmental noises and occasional disturbance. There is variety of method modification: low-pass filtering to remove 
interferences, limiting the time interval between two peaks, use of vertical acceleration data for smartphone position constraints.

Zero crossing method of step counting is based on the detection of zero points in accelerometer vector magnitude [1]. Again, the sensor readings must be pre-filtered to smooth the instrument noises.

For both methods, zero crossing and peaks detection there is the problem of unconstrained manner of smartphone holding.

The most interesting method is the normalized auto-correlation based step counting [5], [7], since it works directly with periodical nature of walking.

\section{PROBLEM STATEMENT}

All sensors in smartphone work in body-fixed (or sensor) coordinate system (Fig. 1), that has the connection with navigation frame NED or ENU and correspondingly can be converted in latitude $(\varphi)$ and longitude $(\lambda)$ coordinates.

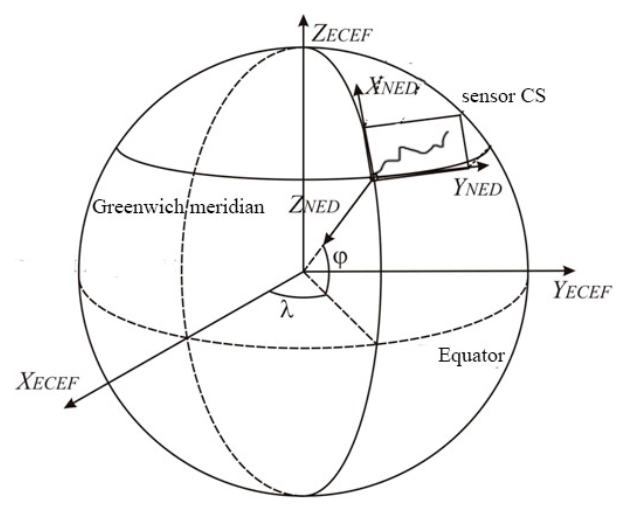

Fig. 1. Coordinate systems

Assuming the standard set of IMU sensors in mobile phone the following data are used for further consideration and processing.

Accelerations. MEMS-accelerometers provide three components of acceleration vector $a_{m}=\left(a_{x}, a_{y}, a_{z}\right)$. Optionally the readings of accelerometers can be already calibrated and filtered from thermal noises.

The magnitude of acceleration vector is found as:

$$
a_{m}=\sqrt{a_{x}^{2}+a_{y}^{2}+a_{z}^{2}},
$$

Orientation. The output of MEMS-gyroscopes are angular rates $\omega=\left(\omega_{x}, \omega_{y}, \omega_{z}\right)$ in sensor coordinate system. In most mobile phone there is built-in calculation of attitude angles (again in sensor coordinate system): roll $\gamma$, pitch $\vartheta$, yaw $\psi$.

Inertial Measurement Unit readings needs to be interpreted depending on the walking type.
Generally [6] the transmission between walking phases (Fig. 2) is accompanied by the respective change of acceleration. That is why most of the method of step detection and counting are based on processing the acceleration vector magnitude (1).

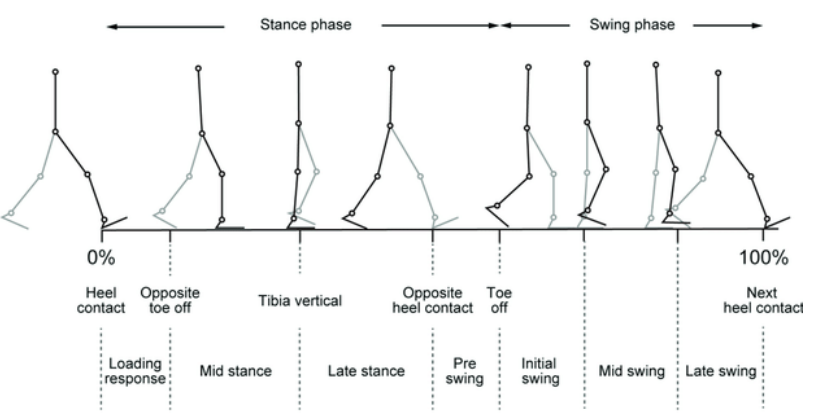

Fig. 2. Walking phases by [6]

Here the periodic pattern is clearly seen, the same as it can be seen on accelerometer readings (Fig. 3).

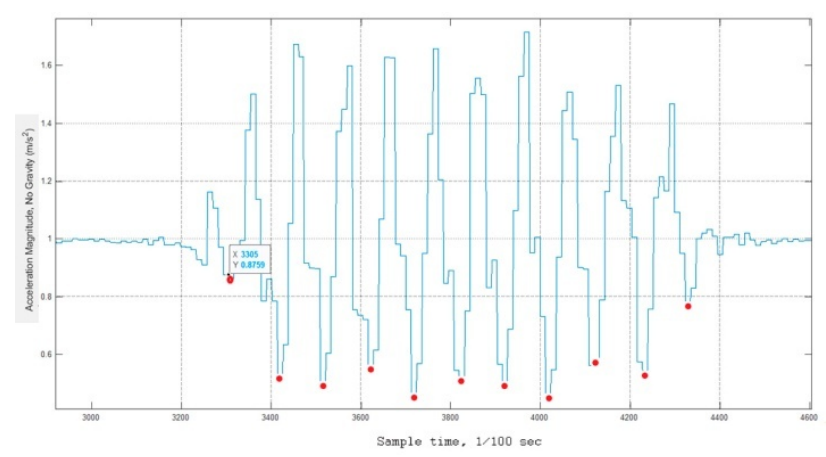

Fig. 3. Accelerometer readings for idle and walking

The magnitude of acceleration vector must be preprocessed to eliminate gravity components

$$
a_{n g}=a_{m}-g,
$$

and filtered to delete random noises by low-pass filter with cut-off frequency corresponding to the update sensor rate. The filter can be realized by moving average window:

$$
a_{\text {filtered }}(i)=\frac{1}{T} \cdot \sum_{j=-(T-1) / 2}^{(T-1) / 2} a_{n g}(i+j),
$$

where $T$ is the size of moving window [8].

The autocorrelation function $\rho(\tau)$ used in the step calculation is proposed to represent as following:

$$
\rho(\tau)=\frac{\sum_{k=1}^{N-\tau}\left(a_{k}-\bar{a}\right)\left(a_{k+\tau}-\bar{a}\right)}{\sum_{k=1}^{N}\left(a_{k}-\bar{a}\right)^{2}},
$$

where $a_{k}$ is the specific value of acceleration magnitude in time moment $k, \tau$ is the time lag between compared sequences, $N$ is the sequence length $(2 \tau)$. 
The autocorrelation function (4) is normalized, that is, the metrics of similarity will be in the range $[-1,+1]$. The problem addressed in [7] is related to the finding the optimal value of time lag $\tau$.

The standard pace frequency of human walking is about $1 \mathrm{~Hz}$. In Figure 3 with sensor update rate at $100 \mathrm{~Hz}$, the time lag correspondingly is varied from 91 to 127 . The optimal time lag can be found by varying its value in additional calculation loop, but the computing efficiency of such approach will be degraded.

Another problem referred to autocorrelation method is the false counting of steps at the idle mode or phone jittering. Again, in Fig. 3 it is seen the periodic character of acceleration reading from 3000 to 3200 sample times where the pedestrian is standing, not walking.

That is why the autocorrelation method is combined with additional techniques like thresholding. Simple threshold is selected by standard deviation, for example, idle mode is determined if

$$
\sigma\left(a_{m}\right)<0.01 \text {. }
$$

In this case the autocorrelation function (ACF) is not calculated. If the condition (5) is not fulfilled then the walking mode is supposed, and ACF is checked, whether is greater than threshold. If yes, then step counting is incremented by one.

Such thresholding is realized in Fig. 4, where for the step value of ACF is taken 0.7.
The one more problem of autocorrelation method is connected with the necessity to work with long sequences (means either offline processing of data or delay in step counting if working in real time modes). Also the computing sufficiency of method is lower than methods of peak detection or zero crossing.

\section{EXPERIMENT DESCRIPTION}

Experiments have been conducted using sensors of smartphone, namely a set of IMU by BMI160, and K6DS3TR from STM. Both of them are low noise 16-bit IMUs designed for mobile applications such as indoor navigation, providing highly accurate sensor data and real-time sensor data.

The trajectory of walking for checking the peaks detection and zero crossing methods is shown in Fig. 5. During the experiments the type of walking has been varied (fast / slow) and smartphone holding (in hands/in the pocket).

The error of step detection method is determined by difference between true number of steps $N$ and counted number of steps $N_{c}$ :

$$
\Delta=\left(1-\frac{\left|N-N_{c}\right|}{N}\right) \cdot 100 \% .
$$

The data have been processed and represented in Table I.

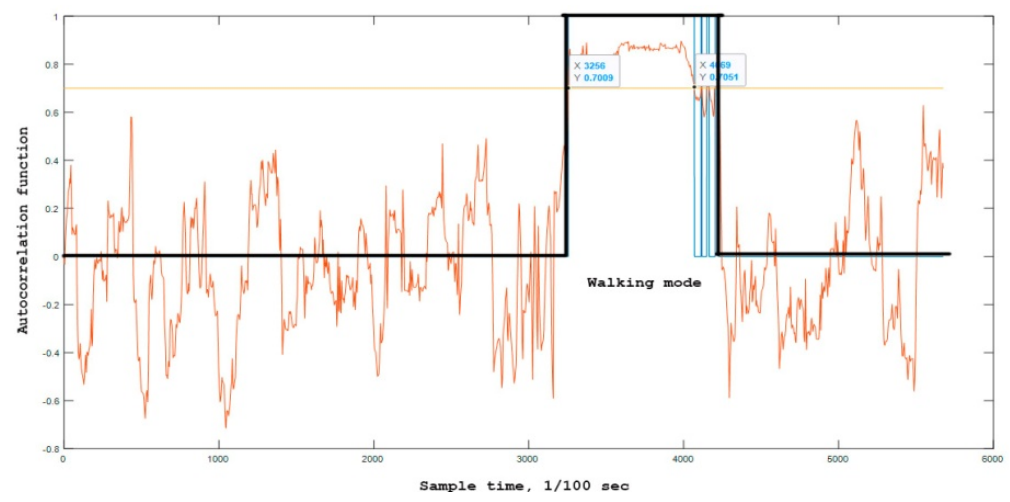

Fig. 4. Detection by ACF of walking and idle modes

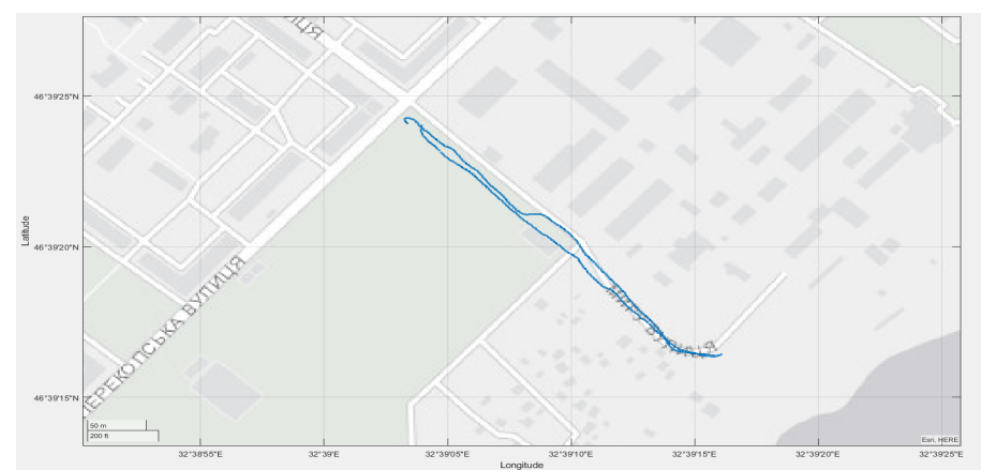

Fig. 5. Trajectory of walking 
For autocorrelation step counting method the trajectory has been selected much shorter, approximately 100 steps (Fig. 6).

By the readings of accelerometer (Fig. 7) the periods of idle and walking are clearly seen, the value of threshold is determined by the standard deviation (std).
By using the thresholding and autocorrelation function the readings corresponding to the walking mode are separated (Fig. 8) and then processed.

The data by autocorrelation method have been processed and represented in Table II.

Table I. Quality of Step Detection Methods

\begin{tabular}{|c|c|c|c|c|}
\hline \multirow[t]{5}{*}{ Method } & Walking type & Type of phone use & $\begin{array}{l}\text { Quality of step counting by } \\
\text { zero crossing }\end{array}$ & $\begin{array}{c}\text { Quality of step counting } \\
\text { by peaks detection }\end{array}$ \\
\hline & slow & in hands & $\begin{array}{l}N=907, N_{c}=933 \\
Q=97 \%\end{array}$ & $\begin{array}{l}N=907, N_{c}=1003 \\
Q=90 \%\end{array}$ \\
\hline & slow & in the pocket & $\begin{array}{l}N=925, N_{c}=962 \\
Q=94 \%\end{array}$ & $\begin{array}{l}N=925, N_{c}=1364 \\
Q=53 \%\end{array}$ \\
\hline & $\begin{array}{l}\text { fast, longer } \\
\text { trajectory }\end{array}$ & in hands & $\begin{array}{l}N=823, N_{c}=780 \\
Q=95 \%\end{array}$ & $\begin{array}{l}N=823, N_{c}=549 \\
Q=67 \%\end{array}$ \\
\hline & $\begin{array}{l}\text { fast, longer } \\
\text { trajectory }\end{array}$ & in the pocket & $\begin{array}{l}N=810, N_{c}=642 \\
Q=79 \%\end{array}$ & $\begin{array}{l}N=810, N_{c}=777 \\
Q=96 \%\end{array}$ \\
\hline
\end{tabular}

TABLE II. QUALITY OF AUtOCORRELATION METHOD

\begin{tabular}{|c|c|c|c|c|c|c|}
\hline \multicolumn{3}{|c|}{ Method } & $\begin{array}{c}\text { Quality of } \\
\text { step counting } \\
\text { by zero } \\
\text { crossing }\end{array}$ & $\begin{array}{l}\text { Quality of step } \\
\text { counting by } \\
\text { peaks detection }\end{array}$ & $\begin{array}{c}\text { Quality of } \\
\text { normalized auto- } \\
\text { correlation (mean) }\end{array}$ & $\begin{array}{c}\text { Quality of } \\
\text { normalized } \\
\text { auto-correlation } \\
\text { (median) }\end{array}$ \\
\hline \multirow{2}{*}{$\begin{array}{l}\text { Walking } \\
\text { type / } \\
\text { Type of } \\
\text { phone } \\
\text { use }\end{array}$} & normal & in hand & $\begin{array}{l}N=100 \\
N_{c}=91 \\
Q=91 \%\end{array}$ & $\begin{array}{l}N=100 \\
N_{c}=99 \\
Q=99 \%\end{array}$ & $\begin{array}{l}N=100, \\
N_{c}=100 \\
Q=100 \%\end{array}$ & $\begin{array}{l}N=100 \\
N_{c}=101 \\
Q=99 \%\end{array}$ \\
\hline & normal & $\begin{array}{l}\text { in the } \\
\text { bag }\end{array}$ & $\begin{array}{l}N=100 \\
N_{c}=157 \\
Q=43 \%\end{array}$ & $\begin{array}{l}N=100, \\
N_{c}=165 \\
Q=35 \%\end{array}$ & $\begin{array}{l}N=100, \\
N_{c}=117 \\
Q=83 \%\end{array}$ & $\begin{array}{l}N=100, \\
N_{c}=115 \\
Q=85 \%\end{array}$ \\
\hline
\end{tabular}

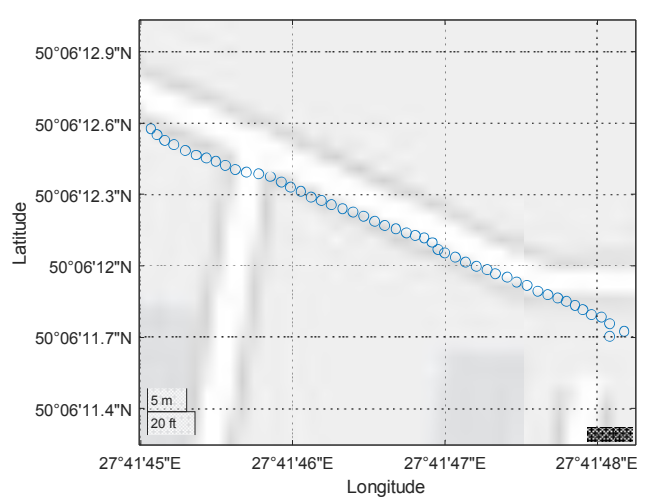

Fig. 6. Testing trajectory for autocorrelation step counting

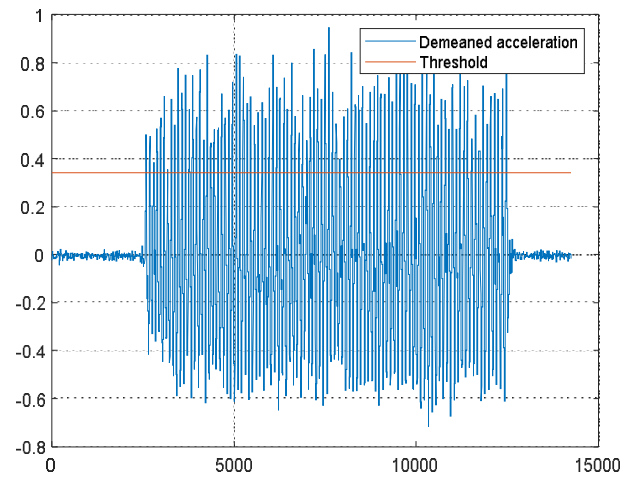

Fig. 7. Accelerometer readings with threshold value

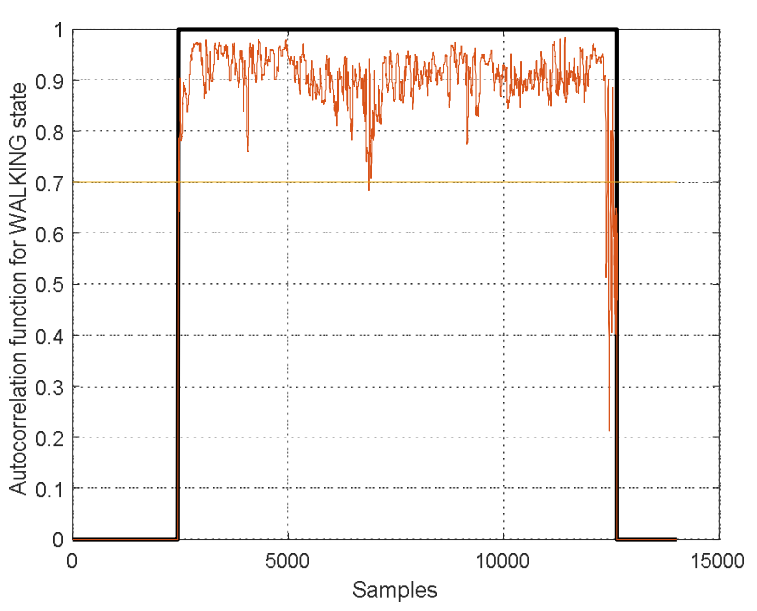

Fig. 8. Accelerometer readings with threshold value

\section{CONCLUSIONS}

The investigated methods of step counting provide accurate results for the constrained holding of smartphone (strictly in hands) and differ in the computing efficiency. Both of peaks detection and zero crossing are of good speed of response and can operate in real time mode to calculate step for the task of active pedestrian dead reckoning. When the smartphone is in the hands/bags, the accuracy radically drops up to $40-50 \%$. 
The autocorrelation method can be used for offline processing since it involves heavy calculation. Even for unconstrained using of smartphone this method demonstrate the quality higher than $80 \%$.

\section{REFERENCES}

[1] S. Beauregard and H. Haas, "Pedestrian dead reckoning: A basis for personal positioning," in Proceedings of the 3rd Workshop on Positioning, Navigation and Communication, March 2006, pp. 27-35.

[2] A. R. Jimenez, F. Seco, C. Prieto, and J. Guevara, "A comparison of pedestrian dead-reckoning algorithms using a low-cost MEMS IMU," in 2009 IEEE International Symposium on Intelligent Signal Processing, August 2009, pp. 37-42.

[3] P. Kasebzadeh, C. Fritsche, G. Hendeby, F. Gunnarsson, and F. Gustafsson, "Improved pedestrian dead reckoning positioning with gait parameter learning," in 2016 19th International Conference on Information Fusion (FUSION), July 2016, pp. 379-385.

[4] A. Brajdic, R. Harle, "Walk detection and step counting on unconstrained smartphones," in Proceedings of the 2013 ACM international joint conference on Pervasive and ubiquitous computing,
September, 2013, pp.

225-234. https://doi.org/10.1145/2493432.2493449

[5] B. Huang, G. Qi, X. Yang, L. Zhao, and H. Zou, "Exploiting cyclic features of walking for pedestrian dead reckoning with unconstrained smartphones," in Proceedings of the 2016 ACM International Joint Conference on Pervasive and Ubiquitous Computing, September, 2016, pp. 374-385. https://doi.org/10.1145/2971648.2971742

[6] B. Kibushi, S. Hagio, T. Moritani, and M. Kouzaki, "Speed-dependent modulation of muscle activity based on muscle synergies during treadmill walking," Human Neuroscience, 2018, 12, p. 4. https://doi.org/10.3389/fnhum.2018.00004

[7] A. Rai, K. K. Chintalapudi, V. N. Padmanabhan, and R. Sen, "Zee: Zero-effort crowdsourcing for indoor localization," in Proceedings of the 18th annual international conference on Mobile computing and networking, August 2012, pp. 293-304. https://doi.org/10.1145/2348543.2348580

[8] A. R. Pratama and R. Hidayat, "Smartphone-based pedestrian dead reckoning as an indoor positioning system," in 2012 International Conference on System Engineering and Technology (ICSET), September 2012, $\quad$ pp. $1-6$. https://doi.org/10.1109/ICSEngT.2012.6339316

Received 31 March 2020.

Mukhina Maryna. Doctor of Engineering Science. Associate Professor.

Faculty of Air Navigation, Electronics and Telecommunications, National Aviation University, Kyiv, Ukraine.

Education: National Aviation University, Kyiv, Ukraine, (2002).

Research area: images processing, navigation and control, aided navigation.

Publications: more than 60 papers.

E-mail: marinamukhina79@gmail.com

Ilnytska Svitlana. orcid.org/0000-0003-2568-8262. Candidate of Science (Engineering).

Wenzhou University, Wenzhou, China.

Education: National aviation university, Kyiv, Ukraine, (2004).

Research area: air navigation, navigation and control systems.

Publications: 50 .

E-mail: Ilnytskasv84@gmail.com

Lazarevsky Oleksandr. Student.

Faculty of Air Navigation, Electronics and Telecommunications, National Aviation University, Kyiv, Ukraine.

Education: National Aviation University, Kyiv, Ukraine.

Напрямок наукової діяльності: air navigation, navigation and control systems.

E-mail: darkkemono@gmail.com

М. П. Мухіна, С. І. Ільницька, О. А. Лазаревський. Порівняння методів підрахунку кроків у часовій області для задачі числення шляху пішохода

Задача підрахунку кроків розглянута для особистої навігації під час ходьби та використання мобільних датчиків із низькою точністю. Підрахунок кроків був реалізований трьома основними способами обробки модуля вектора прискорення у часовій області. Порівняння цих методів було здійснено під час обробки даних 3 датчиків мобільних телефонів для різних умов та типів руху пішоходів. Для того, щоб мати репрезентативну статистику, пішохідні траєкторії були вибрані досить протяжними (принаймні 100 метрів), за винятком методу нормованого підрахунку кроків, заснованого на автокореляції, де оброблені короткі відстані. Сформульовано вимоги до визначеного способу підрахунку кроків.

Ключові слова: числення шляху пішохода; автокореляційна функція; встановлення порогових значень; виявлення піків; підрахунок переходів через нуль. 
Мухіна Марина Петрівна. Доктор технічних наук. Доцент.

Факультет аеронавігації, електроніки та телекомунікацій, Національний авіаційний університет, Київ, Україна. Освіта: Національний авіаційний університет, Київ, Україна, (2002).

Напрямок наукової діяльності: обробка зображень, навігація та управління, комплексні навігаційні системи.

Кількість публікацій: більше 60.

E-mail: marinamukhina79@gmail.com

Ільницька Світлана Іванівна. Кандидат технічних наук. Науковий співробітник.

Інститут лазерного та оптоелектронного інтелектуального виробництва, Університет Венжоу, Венжоу, Китай. Освіта: Національний авіаційний університет, Київ, Україна, (2007).

Напрямок наукової діяльності: навігація та управління, інтегровані навігаційні системи, супутникові та інерціальні навігаційні системи, технології калібрування датчиків, комп’ютерне моделювання

Кількість публікацій: 50.

E-mail: ilnytskasv84@gmail.com

Лазаревський Олександр Андрійович. Студент.

Факультет аеронавігації, електроніки та телекомунікацій, Національний авіаційний університет, Київ, Україна. Освіта: Національний авіаційний університет, Київ, Україна.

Напрямок наукової діяльності: обробка зображень, навігація та управління, комплексні навігаційні системи.

E-mail: darkkemono@gmail.com

М. П. Мухина, С. И. Ильницкая, А. А. Лазаревский. Сравнение методов подсчета шагов во временной области для задачи счисления пути пешехода

Задача подсчета шагов рассмотрена для личной навигации во время ходьбы и использования мобильных датчиков с низкой точностью. Подсчет шагов был реализован тремя основными способами обработки модуля вектора ускорения во временной области. Сравнение этих методов было осуществлено во время обработки данных с датчиков мобильных телефонов для различных условий и типов движения пешеходов. Для того, чтобы иметь репрезентативную статистику, пешеходные траектории были выбраны достаточно протяженными (по крайней мере 100 метров), за исключением метода нормированного подсчета шагов, основанного на автокорреляции, где обработаны короткие расстояния. Сформулированы требования к определенному способу подсчета шагов.

Ключевые слова: исчисление пути пешехода; автокорреляционная функция; установление пороговых значений; выявление пиков; подсчет переходов через ноль.

Мухина Марина Петровна. Доктор технических наук. Доцент.

Факультет аэронавигации, электроники и телекоммуникаций, Национальный авиационный университет, Киев, Украина.

Образование: Национальный авиационный университет, Киев, Украина, (2002).

Направление научной деятельности: обработка изображений, навигация и управления, комплексные навигационные системы.

Количество публикаций: более 60.

E-mail: marinamukhina79@gmail.com

Ильницкая Светлана Ивановна. Кандидат технических наук. Научный сотрудник.

Институт лазерного и оптоэлектронного интеллектуального производства, Университет Венжоу, Венжоу, Китай. Образование: Национальный авиационный университет, Киев, Украина, (2007).

Направление научной деятельности: навигация и управления, интегрированные навигационные системы, спутниковые и инерциальные навигационные системы, технологии калибровки датчиков, компьютерное моделирование

Количество публикаций: 50.

E-mail: ilnytskasv84@gmail.com

Лазаревский Александр Андреевич. Студент.

Факультет аэронавигации, электроники и телекоммуникаций, Национальный авиационный университет, Киев, Украина.

Образование: Национальный авиационный университет, Киев, Украина.

Направление научной деятельности: обработка изображений, навигация и управления, комплексные навигационные системы.

E-mail: darkkemono@gmail.com 